\title{
6. DISTRIBUTION OF LATE NEOGENE AND QUATERNARY BENTHIC FORAMINIFERS IN THE NORTHWEST ATLANTIC, DEEP SEA DRILLING PROJECT LEG 93, SITES 603 AND 6041
}

\author{
Laure Blanc-Vernet, Laboratoire de Géologie Marine, Université de Marseille-Luminy \\ and \\ Michel Moullade, Laboratoire de Micropaléontologie et de Géologie Marines, Université de Nice²
}

\begin{abstract}
Eighty-one benthic foraminifer species were recognized in Neogene and Quaternary sediments drilled in DSDP Holes $603 \mathrm{C}$ and 604 .

Hole $603 \mathrm{C}$ is characterized by low benthic foraminiferal number. All the species present are known to inhabit deep water in the modern oceans. Values for specific diversity vary from 10 to 25 species per sample and are inversely proportional to species abundance. Analysis of the composition of the benthic foraminiferal assemblages indicates that Site 603 was probably situated in a transitional zone under the simultaneous influence of both Antarctic Bottom Water and North Atlantic Deep Water during the Neogene and Quaternary.

Hole 604 contains greater abundances of benthic specimens than Hole $603 \mathrm{C}$. Bathyal-abyssal autochthonous assemblages dominate in Recent/Holocene, lowermost Quaternary and Pliocene sediments, whereas most of the Quaternary and the upper Miocene are characterized by mixing of shallow-water and deep-water species. Periods of redeposition of displaced neritic foraminifers appear to be synchronous with periods when there was increased influx of coarser detritic material to the oceanic basin.
\end{abstract}

\section{INTRODUCTION}

Holes $603 \mathrm{C}$ and 604 of DSDP Leg 93 are located in the northwest Atlantic, on the lower and upper continental rise, at 4633 and $2361 \mathrm{~m}$ water depth, respectively (Fig. 1). These sites were chosen for study because they offer the most continuous and complete sequences of Neogene and Quaternary deposits drilled during Leg 93. Because the two sites differ in physiographic settings, distances from the coast, and water depths, their benthic foraminiferal assemblages are considered separately.

\section{METHODS}

The methods used to separate foraminifers from the sediment are described by Moullade and by Ma'alouleh and Moullade (both this volume). Briefly, the sediment was dried, weighed, boiled in Calgon solution, and washed in a $63-\mu \mathrm{m}$ sieve. For paleoecological studies, only tests larger than $160-\mu \mathrm{m}$ were considered. The residue was eventually microsplit and all the benthic forms were picked.

In Hole 604, the benthic foraminifers were frequent enough to permit calculation of significant percentages. In Hole 603C, the benthic microfauna was too sparse for such precision and the frequencies of the different taxa were estimated within size classes $(0-5 \%, 5-10 \%$, $10-20 \%, 20-40 \%,>40 \%$ ).

\section{HOLE 603C}

\section{Distribution of Benthic Foraminifers}

The vertical distribution of the more frequent and constant benthic taxa is shown in Figure 2. Two groups can be distinguished:

\footnotetext{
1 van Hinte, J. E., Wise, S. W., Jr., et al., Init. Repts. DSDP, 93: Washington (U.S. Govt, Printing Office).

2 Addresses: (Blanc-Vernet) Laboratoire de Géologie Marine, Université de MarseilleLuminy, Case 901, 13288 Marseille Cedex 9, France; (Moullade) Laboratoire de Micropaléontologie et de Géologie Marines, Université de Nice, Parc Valrose, 06034 Nice Cedex, France.
}

1. Species that are present throughout the hole: Osangularia umbonifera and Pullenia spp. Melonis formosum is also constantly present but in small quantities, and it is not shown in Figure 2.

2. Species with a more restricted distribution: Oridorsalis umbonatus and Eggerella bradyi are present from the bottom of the hole to Sample 603C-6-3, 90-94 cm; Planulina wuellerstorfi and Globocassidulina subglobo$s a$ extend from the bottom of the hole to Samples 603C$14-3,90-94 \mathrm{~cm}$ and $603 \mathrm{C}-17-3,90-94 \mathrm{~cm}$, respectively; Melonis barleeanum is present from Core 10 to Core 5; $M$. pompilioides occurs from the bottom of the hole to Sample 603C-11-2, 90-94 cm; Various species of the genus Gyroidina are found mostly between Cores 30 and 17; Ehrenbergina sp. was found only in the lower Pliocene part of the hole and disappeared at the top of Zone PL1.

All these species except perhaps Ehrenbergina sp. are still living in the North Atlantic Ocean and cannot be used as stratigraphic indexes. Their distribution may be controlled by paleoenvironmental factors that will be discussed later.

\section{Quantitative Distribution}

\section{Species Abundance and Diversity}

The number of benthic foraminifers per gram of sediment is very low in this hole, especially in the lowest Pliocene, and never exceeds 7-8 specimen/g. According to Ma'alouleh and Moullade (this volume), the abundance of planktonic foraminifers is also low, but the state of preservation of the tests and the composition of the planktonic assemblage suggest that the material is not affected by carbonate dissolution. The scarcity of 


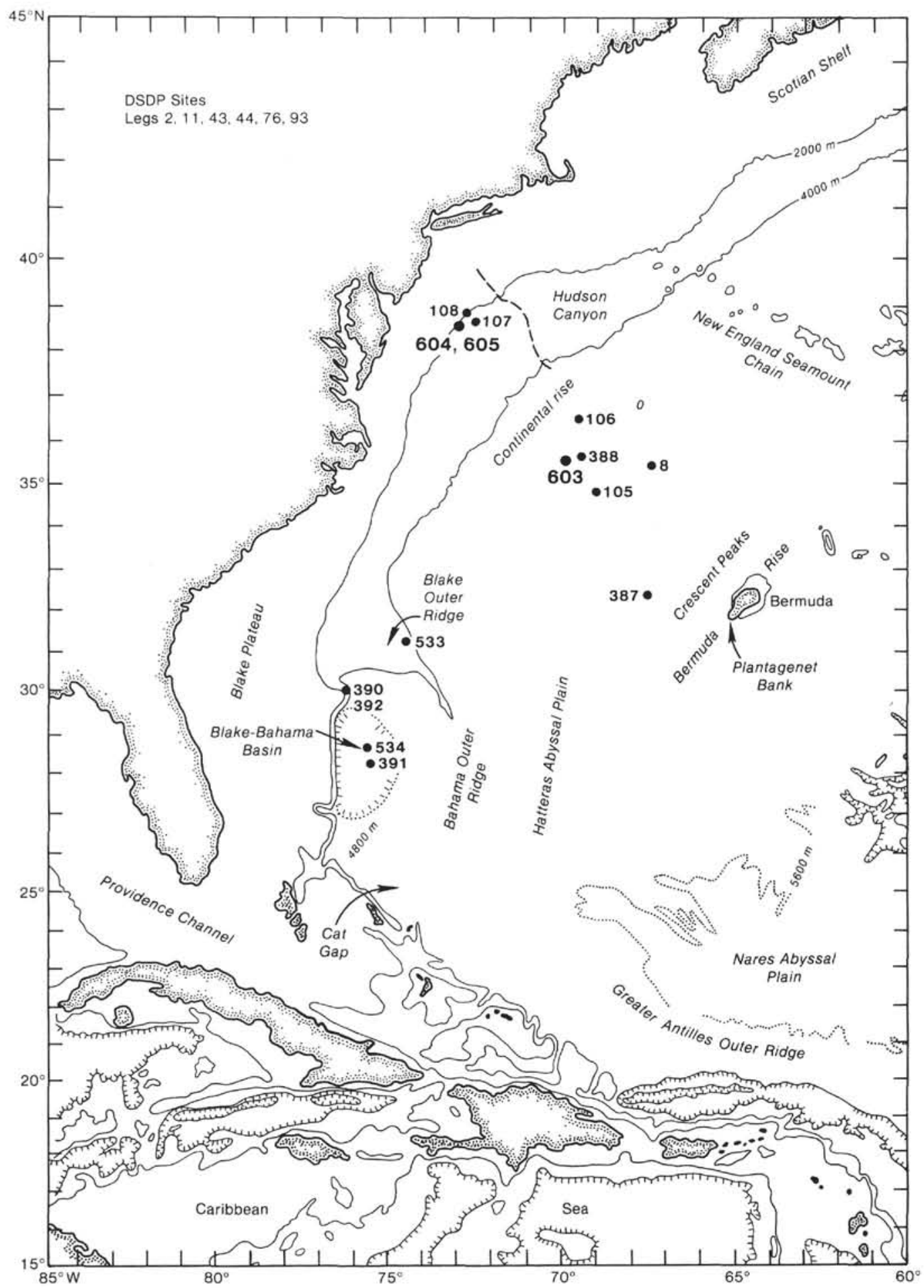

Figure 1. Location of Sites 603 and 604.

both benthic and planktonic foraminifers is, therefore, tentatively interpreted as a consequence of the high rate of sedimentation.

Nevertheless, more than 50 species were recognized in the 52 samples examined in our study. The number of species per sample varies greatly from one sample to another. But paradoxically, the specific diversity increases downhole as the number of specimens decreases. In Pleis- tocene and uppermost Pliocene sediments, we observed a maximum of 10 species per sample, whereas there was a mean of 15 taxa per sample in the mid-upper Pliocene (Zones PL3 to PL5), and 20-25 in the lower Pliocene (Zone PL1). The species frequencies plotted in Figure 3, column $\mathrm{C}$ are the means of the values for each species in the samples from each biostratigraphic zone (PL1, PL3, PL4, PL5, and Pleistocene). 


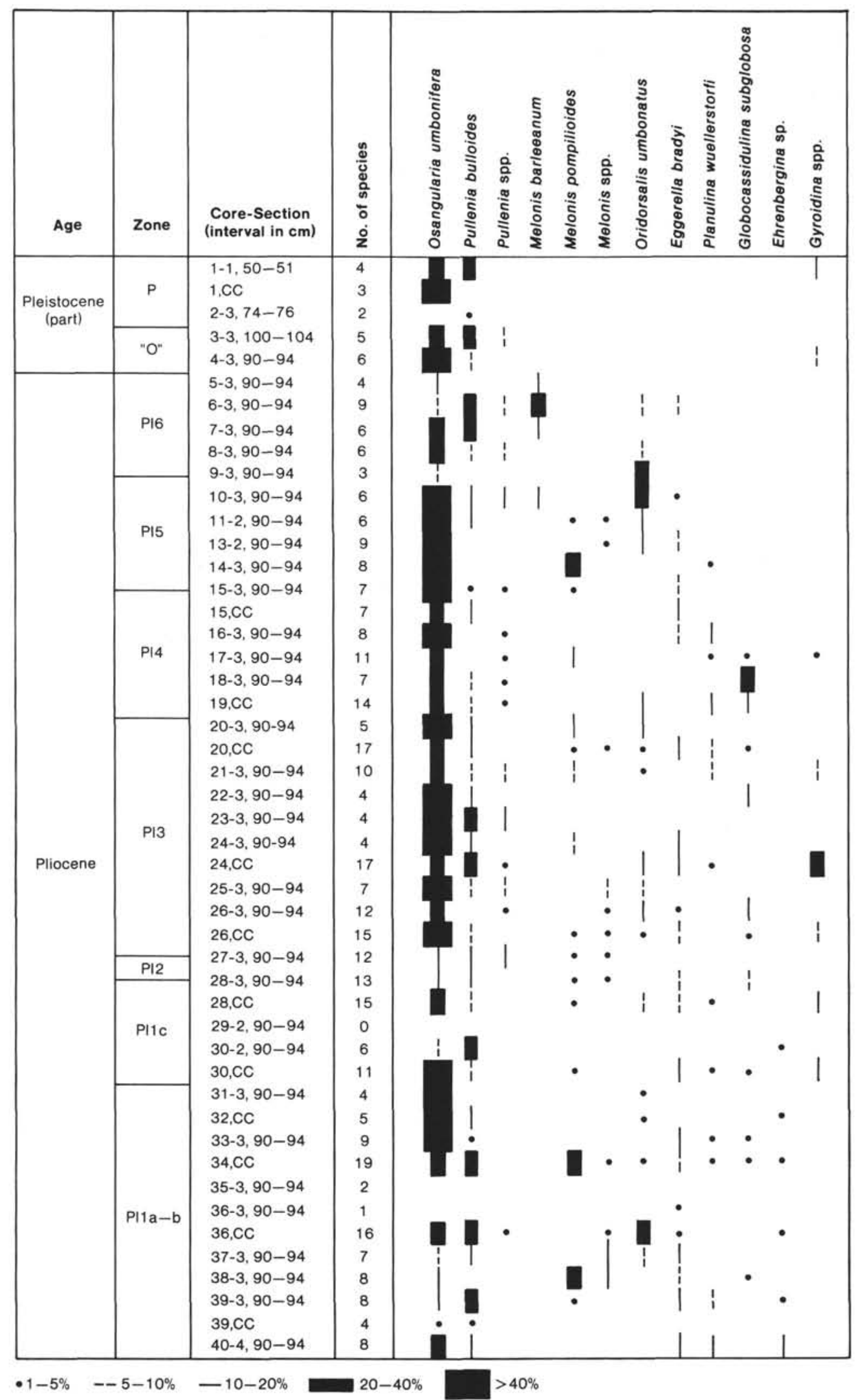

Figure 2. Vertical distribution of selected benthic foraminiferal species, Hole 603C. Ages and zones from Ma'alouleh and Moullade, this volume. 


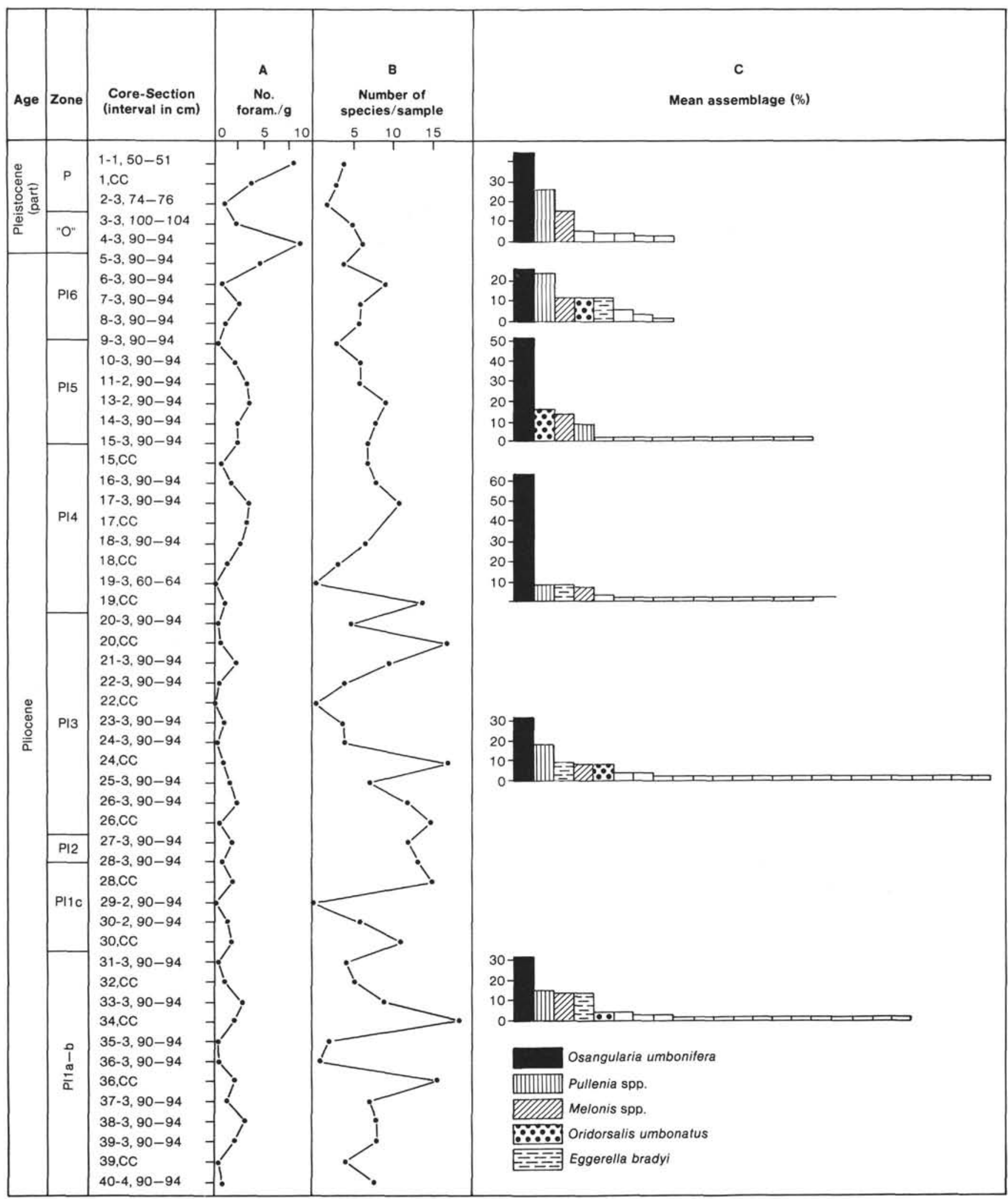

Figure 3. Variations in the benthic foraminiferal assemblages, Hole $603 \mathrm{C}$. The species percentages represent the average values of the frequencies for the different samples of each biozone (PL1, PL3, PL4, PL5, and Pleistocene; the two samples of Zone PL2 are very poor and are not taken in account). Ages and zones from Ma'alouleh and Moullade, this volume. Unmarked boxes represent other taxa. 


\section{Species Dominance}

Species belonging to five genera dominate the benthic microfauna in Hole $603 \mathrm{C}$, and together constitute more than $75 \%$ of the assemblages: Osangularia umbonifera, Pullenia bulloides, Pullenia spp., Melonis barleeanum, M. pompilioides, Melonis spp., Oridorsalis umbonatus, and Eggerella bradyi.

\section{Paleoenvironmental Interpretation}

All taxa found in Hole $603 \mathrm{C}$ are known to live at great depths in present-day oceans. Very few displaced shallow-water forms were found. In descriptions of North Atlantic benthic foraminiferal populations, several authors (e.g., Streeter, 1973; Weston and Murray, 1984) consider Osangularia umbonifera to be an important component of Antarctic Bottom Water fauna, whereas Oridorsalis umbonatus (generally accompanied by Epistominella exigua) characterizes populations living under the influence of the North Atlantic Deep Water. Schnitker $(1974,1980)$ suggests that these two faunas become indistinguishable south of $35-45^{\circ}$ latitude.

In Hole $603 C, E$. exigua is present in only one sample (603C-17-3, 90-94 cm). Another component of the North Atlantic Deep Water assemblage, Planulina wuellerstor$f i$, occurs sporadically below Sample 603C-14-3, 90-94 $\mathrm{cm}$ and is absent above this level; but $O$. umbonatus and Osangularia umbonifera always occur together in abundance. This observation leads us to suggest that Site 603 may be situated in a transitional zone in which the two populations were mixed.

\section{HOLE 604}

The number of benthic foraminifers per sample is very irregular in Hole 604 but is generally much greater than in Hole $603 \mathrm{C}$. The composition of the different assemblages is also less homogeneous, containing species which are characteristic of different bathymetric zones.

The qualitative and quantitative variations in the benthic assemblages of Hole 604 are depicted in Fig. 4.

\section{Distribution of Benthic Species}

Most of the forms encountered are known to inhabit bathyal realms of the modern oceans (Phleger et al., 1953; Lohmann, 1978; Lutze, 1978; Ingle et al., 1980), but in many samples these deep-water forms are accompanied by specimens usually living in shallower environments. These specimens are considered as displaced. A third group is composed of fossil forms, no longer represented in modern seas; these occur only below Sample 604-7, CC and include representatives of the family Nodosariidae and the genus Siphogenerina. These may have been bathyal forms, but no direct comparison can be made with recent homologs.

The species are divided into three groups according to bathymetric and stratigraphic significances (Fig. 4):

\section{Neritic Species}

An important fraction of this group originates from the inner shelf: Ammonia beccarii, Elphidium incertum, and Nonionella spp. Another part is composed of spe- cies known to inhabit the outer shelf (and even the upper slope): Textularia spp., Bulimina marginata, B. aculeata, Cassidulina carinata, Trifarina angulosa, Cancris oblongus, and Heterolepa pseudoungerianus.

\section{Deep Species}

In this group, three subgroups were differentiated:

a. Uvigerina ex gr. peregrina, which constitutes the main component of the Recent benthic microfauna living at the present depth of Hole $604(\sim 2300 \mathrm{~m})$. During the Quaternary, the abundance of this form was probably controlled by the water masses rather than by depth (cf. Schnitker, 1980).

b. Bathyal species, with a wide bathymetric distribution including the entire bathyal realm.

c. Bathyal-abyssal species, inferred to have an upper depth limit of $1000 \mathrm{~m}$ and below (Pflum and Frerichs, 1976): Pyrgo lucernula, Quinqueloculina venusta, Osangularia culter, Uvigerina senticosa, and others.

\section{Fossil Species}

These forms became extinct at the end of the Pliocene or in the early Pleistocene. They comprise several species of Nodosariidae (with genera such as Lenticulina, Dentalina etc.) plus Stilosiomella ex. gr. lepidula and Plectofrondicularia advena. These two latter forms are often considered to be useful stratigraphic markers, because their extinction is thought to coincide with the beginning of the magnetostratigraphic Brunhes Chron (Lutze, 1979). In Hole 604, as well as at Site 533 (BlancVernet, 1983), these species disappear in climatic zone T as defined by Ericson and Wollin (1968). The middle part of this zone has been shown to correspond with the lower limit of the Brunhes Chron (=0.69 Ma, Briskin and Berggren, 1975).

\section{Quantitative Distribution}

Hole 604 can be subdivided into six sequences according to quantitative variations in the benthic foraminiferal content (Fig. 4).

\section{Sequence 1: Interval Comprising Sample 604-1, top and $604-1-1,11-12 \mathrm{~cm}$}

We assume that the benthic microfauna found in this "top water" sample reflects the population living and/ or deposited at the present depth of the hole. The deepwater group constitutes more than $90 \%$ of the assemblage. Dominant forms are Uvigerina ex. gr. peregrina $(42 \%)$, Globobulimina pyrula and G. affinis (20\% together), and Hoeglundina elegans (10\%). Pyrgo murrhina, Planulina wuellerstorfi, Cibicidoides robertsonianus, Karreriella bradyi, Chilostomella oolina and Melonis sp. are also present. Some other forms such as Bulimina aculeata, B. marginata, and Lagena spp., are known to have a wider bathymetric distribution. Only one species (Nonionella opima, $1.5 \%$ ) can be interpreted as being displaced from the inner shelf.

Sample 604-1-1, 11-12 cm contains a very similar assemblage; we suggest that benthic contamination from the shelf was low at Site 604 in latest Holocene and Recent times. 


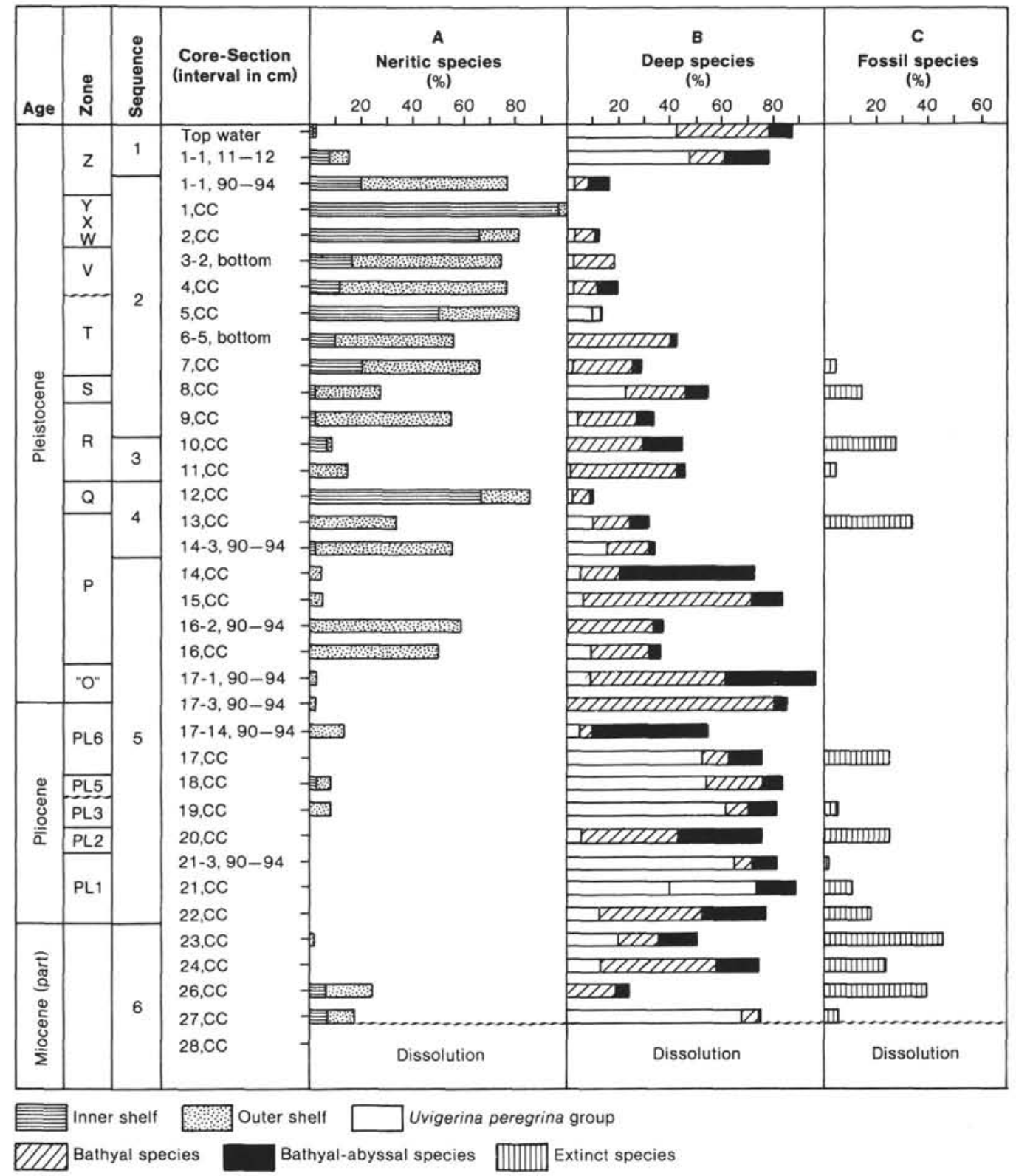

Figure 4. Composition of the benthic foraminiferal assemblages, Hole 604. Total of the three columns does not always equal $100 \%$, because in some samples small numbers of benthic foraminifers remained specifically unidentified; they do not appear on the diagram but were included in the quantitative estimate. Ages and zones from Moullade, this volume. Extinct species consist of pre-Pleistocene taxa (see text).

Sequence 2: Interval from Samples 604-1-1, 90-94 cm to $604-9, \mathrm{CC}$

In marked contrast to the interval described above, the deep-water species in sequence 2 never exceed $50 \%$ of the assemblage and are often less than $20 \%$, particularly in the upper part of this sequence. Uvigerinids become rare $( \pm 5 \%)$ or absent. Allochthonous neritic species abound (20 to 100\%) and are diverse. The most frequent species are Nonionella opima, N. sp., Elphidium incertum, E. ex. gr. excavatum, E. subarcticum, and several neritic miliolids (Quinqueloculina seminulum, Triloculina spp.).

Moullade (this volume) described variations in global abundance of both benthic and planktonic foraminifers and noted that some of the maxima evidenced by the two curves are synchronous. He tentatively ascribed this to hydrodynamic winnowing. When maxima occur simultaneously with peaks of displaced neritic benthic species, such as in sequence 2 , we suspect that the foraminiferal assemblage in the samples was mainly formed by transportation and redeposition of allochthonous forms. Both benthic and planktonic species would participate in this process.

\section{Sequence 3: Interval Comprising Cores 604-10 and -11}

These two samples are characterized by significant reworking of Miocene material (Moullade, this volume); they contain typical deep-water benthic species. These 
assemblages differ from those of sequence 2 by their lower abundance of shallow-water contaminants and from those of sequence 1 by the absence of uvigerinids.

\section{Sequence 4: Interval from Samples 604-12,CC to 604-14-3, 90-94 cm}

This sequence is marked by assemblages similar to those of sequence 2 , that is, with a predominance of allochthonous components.

\section{Sequence 5: Interval from Samples 604-14,CC to 604-22,CC}

This interval includes the entire Pliocene and the basal Quaternary; the assemblages broadly resemble those of sequence 1 . The number of displaced forms, mostly originating from the outer shelf, is low (less than $20 \%$ ), with the exception of the two samples from Core 16 . The proportion of the deep-water species appears to be slightly greater than in sequence 1 . Percentages of uvigerinid species are high (up to 50\%), particularly in the Pliocene.

\section{Sequence 6: From Sample 604-23,CC to the bottom}

This upper Miocene sequence is characterized by poor preservation of the benthic foraminifers, probably because of intense dissolution. Benthic foraminifers are gradually reduced downhole, and are absent below Sample 604-27,CC. In Cores 604-26 and -27, displaced shallowwater forms (even forms from the inner shelf) occur in percentages of $\pm 20 \%$. At the same level, increased amounts of coarser detrital material are also present, as in sequence 2 .

\section{DISCUSSION}

The benthic foraminiferal assemblages at Site 604 show qualitative and quantitative variations.

The variations in the composition of the in situ bathyal assemblages (consisting primarily of fluctuations in the uvigerinid frequency values) may be due to changes in the properties of the bottom water (organic matter or oxygen contents?). In contrast, the significance of transportation and redeposition of neritic foraminifers and detrital material may be controlled by sea-level variations.

These phenomena are probably largely dependent on alternating glacial/interglacial environments, at least during late Pliocene and Quaternary times; but the number of samples investigated in this preliminary study was insufficient to support precise interpretations. These problems will be further studied by more detailed sampling of sediments from these sites.

\section{CONCLUSION}

An analysis of variations in the composition of benthic foraminiferal assemblages in Holes $603 \mathrm{C}$ and 604 showed that the deeper more distant Hole $603 \mathrm{C}$ was characterized by exclusively autochthonous, deep-water microfaunas, uncontaminated by displaced specimens. In contrast, Hole 604 yielded abundant benthic assemblages. More or less significant amounts of shallow-water forms (even originating from the inner shelf) were mixed with the in situ bathyal-abyssal species, particularly in the mid-upper Pleistocene and upper Miocene. Sporadic, sudden, benthic increases, possibly resulting from hydrodynamic winnowing, also occur in Hole 604. Throughout, benthic productivity remained much higher in Hole 604 than in Hole $603 \mathrm{C}$, where foraminiferal scarcity was exaggerated by the processes of sedimentary dilution.

\section{ACKNOWLEDGMENTS}

M. Moullade is very grateful to DSDP for inviting him to participate in Leg 93. The authors are also indebted to the reviewers for their critical comments and suggestions. Financial support for this study was provided by the Centre National de la Recherche Scientifique under Grants ATP Géologie-Géophysique des Océans, no. 318/366, Jeune Equipe, no. 333 and Recherche Coopérative sur Programme no. 614.

\section{REFERENCES}

Blanc-Vernet, L., 1983. Benthic foraminifers of Site 533, Leg 76 of the Deep Sea Drilling Project-faunal variations during the Pliocene and Pleistocene on the Blake Outer Ridge (western North Atlantic). In Sheridan, R. E., Gradstein, F. M., et al., Init. Repts. DSDP, 76: Washington (U.S. Govt. Printing Office), 497-509.

Briskin, M., and Berggren, W. A., 1975. Pleistocene stratigraphy and quantitative paleoceanography of tropical North Atlantic core V 16-205. In Saito, T., and Burckle, L. H. (Eds.), Late Neogene Epoch Boundaries (Vol. 1): New York (American Museum of Natural History), 167-198.

Ericson, D. B., and Wollin, G., 1968. Pleistocene climates and chronology in deep-sea sediments. Science, 162(3859):1227-1234.

Ingle, J. C., Keller, J. R., and Kolpack, G., 1980. Benthic foraminiferal bio-facies, sediments and water masses of the southern PeruChile Trench area, southern Pacific Ocean. Micropaleontology, 26 (2):113-150.

Lohmann, G. P., 1978. Abyssal benthonic foraminifera as hydrographic indicators in the western South Atlantic Ocean. J. Foraminiferal Res., 8:6-34.

Lutze, G. F., 1978. Neogene benthonic foraminifera from site 369, Leg 41, Deep Sea Drilling Project. In Lancelot, Y., Seibold, E., et al., Init. Repts. DSDP, 41: Washington (U.S. Govt. Printing Office), 659-666.

1979. Benthic foraminifers at Site 397: faunal fluctuations and ranges in the Quaternary. In von Rad, U., Ryan, W. B. F., et al., Init. Repts. DSDP, 47, Pt. 1: Washington (U.S. Govt. Printing Office), $419-432$.

Pflum, C. E., and Frerichs, W. E., 1976. Gulf of Mexico deep water Foraminifera. Cushman Found. Foraminiferal Res. Spec. Publ., $14: 7-125$.

Phleger, F. B., Parker, F., and Peirson, J., 1953. Sediment cores from the North Atlantic Ocean. Repts. Swed. Deep Sea Exped., 7:1-122.

Schnitker, D., 1974. West Atlantic abyssal circulation during the past 120,000 years. Nature, 248:385-387.

1980. Quaternary benthic foraminifers and bottom watermasses. Ann. Rev. Earth Planet. Sci., 8:343-370.

Streeter, S. S., 1973. Bottom water and benthonic foraminifera in the North Atlantic: glacial-interglacial contrasts. Quat. Res., 3:131141.

Weston, J. F., and Murray, J. W., 1984. Benthic foraminifera as deep sea water mass indicators. Second Int. Symp. Benthic Foram., "Benthos 83" Mem. 6, Soc. Nat. Elf-Aquitaine (Prod.), Pau, France., 605-610.

Date of Initial Receipt: 13 February 1985

Date of Acceptance: 20 December 1985

\section{APPENDIX \\ Faunal List}

Adercotryma sp., Ammonia beccarii (Linné), Amphicoryna hirsuta (d'Orbigny), Bolivina ex. gr. spathulata (Williamson), Buccella frigido (Cushman), Bulimina alazanensis Cushman, B. aculeata d'Orbigny, $B$. inflata d'Orbigny, B. spicata Phleger and Parker, Cancris oblongus 
Williamson, Cassidulina carinata (Silvestri), C. subglobosa Brady, Chilostomella oolina Schwager, Cibicides lobatulus Walker and Jacob, C. refulgens Montfort, Cibicidoides robertsonianus (Brady), C. kullenbergi Parker, Dentalina intorta Dervieux, D. subemaciata Parr, Eggerella affixa (Cushman), E. bradyi Cushman, Ehrenbergina sp. Elphidium ex gr. excavatum (Terquem), E. incertum Williamson, Epistominella exigua (Brady), Eponides pusillus Parr, Globobulimina affinis (d'Orbigny), G. pyrula (d'Orbigny), Gyroidina lamarckiana d'Orbigny, G. neosoldanii Brotzen, G. soldanii d'Orbigny, G. cf. umbonata (Silvestri), Heterolepa pseudoungeriana (Cushman), Hoeglundina elegans d'Orbigny, Karreriella bradyi (Cushman), Laticarinina pauperata (Parker and Jones), Lenticulina peregrina (Schwager), Melonis barleeanum (Williamson), M. formosum (Seguenza), M. pompilioides (Fichtel and Moll), Miliolinella circularis (Bornemann), Nodosaria obliquata (Batsch), Nonionella labradorica (Dawson), N. opima Cushman, Nonionella sp., Nummoloculina irregularis (d'Orbigny), Oridorsalis umbonatus (Reuss), Orthomorphina fistuca (Schwager), Osangularia culter (Parker and Jones), O. umbonifera (Cushman), Planulina wuellerstorfi (Schwager), Plectofrondicularia advena (Cushman), Pleurostomella alternans Schwager, Pseudonodosaria laevigata (d'Orbigny), Pullenia bulloides d'Orbigny, P. quinqueloba (Reuss), Pullenia spp., Pyrgo oblonga (d'Orbigny), P. lucernula (Schwager), P. murrhina (Schwager), Pyrulina angusta (Egger), P. fusiformis Roemer, Quinqueloculina arctica Cushman, Quinqueloculina spp., $Q$. venusta Karrer, Robertina bradyi Cushman and Parker, Rosalina sp., Siphotextularia catenata (Cushman), S. curta (Cushman), Sigmoilopsis schlumbergeri (Silvestri), Stilostomella consobrina (d'Orbigny), S. ex. gr. lepidula (Schwager), Sphaeroidinella bulloides d'Orbigny, Textularia earlandi Parker, Triloculina schreibersiana d'Orbigny, Trifarina angulosa (Williamson), Reophax bacillaris Brady, Uvigerina asperula Czjzek, $U$. auberiana d’Orbigny, $U$. peregrina Cushman, $U$. senticosa Cushman.

For illustrations of some important species, see Blanc-Vernet (1983). 